\title{
Impact of Scale and Aggregation on the Terrestrial Water Exchange: Integrating Land Surface Models and Rhône Catchment Observations
}

\author{
RETO STÖCKLI \\ Institute for Atmospheric and Climate Science, ETH Zurich, Zurich, Switzerland, and Department of Atmospheric Science, Colorado \\ State University, Fort Collins, Colorado \\ Pier Luigi Vidale \\ NCAS, Department of Meteorology, University of Reading, Reading, United Kingdom
}

AARON BOONE

CNRM/GAME, Toulouse, France

CHRISTOPH SCHÄR

Institute for Atmospheric and Climate Science, ETH Zurich, Zurich, Switzerland

(Manuscript received 5 July 2006, in final form 31 January 2007)

\begin{abstract}
Land surface models (LSMs) used in climate modeling include detailed above-ground biophysics but usually lack a good representation of runoff. Both processes are closely linked through soil moisture. Soil moisture however has a high spatial variability that is unresolved at climate model grid scales. Physically based vertical and horizontal aggregation methods exist to account for this scaling problem. Effects of scaling and aggregation have been evaluated in this study by performing catchment-scale LSM simulations for the Rhône catchment. It is found that evapotranspiration is not sensitive to soil moisture over the Rhône but it largely controls total runoff as a residual of the terrestrial water balance. Runoff magnitude is better simulated when the vertical soil moisture fluxes are resolved at a finer vertical resolution. The use of subgrid-scale topography significantly improves both the timing of runoff on the daily time scale (response to rainfall events) and the magnitude of summer baseflow (from seasonal groundwater recharge). Explicitly accounting for soil moisture as a subgrid-scale process in LSMs allows one to better resolve the seasonal course of the terrestrial water storage and makes runoff insensitive to the used grid scale. However, scale dependency of runoff to above-ground hydrology cannot be ignored: snowmelt runoff from the Alpine part of the Rhône is sensitive to the spatial resolution of the snow scheme, and autumnal runoff from the Mediterranean part of the Rhône is sensitive to the spatial resolution of precipitation.
\end{abstract}

\section{Introduction}

The overall aim of climate modeling is to gain knowledge about the climate system by using realistic numerical representations of the individual earth system components. Terrestrial hydrology is a key component in coupled climate model simulations (Houghton et al. 2001; Dickinson 2001). While current land surface mod-

Corresponding author address: Reto Stöckli, Institute for Atmospheric and Climate Science, ETH Zürich, 8092 Zürich, Switzerland.

E-mail: stockli@env.ethz.ch els (LSMs) include physically based formulations of plant physiological processes (Sellers et al. 1997; Pitman 2003), soil moisture and runoff are generally poorly represented. Soil moisture varies on much smaller scales than used by atmospheric models (Western et al. 2002) and runoff is controlled by small-scale topographic variability. As suggested by Koster and Milly (1997) and Ducharne et al. (1998) the land surface water balance is controlled as much by evapotranspiration as it is by runoff. The importance of correctly representing soil moisture and runoff processes in climate models has been documented in a number of studies (e.g., Gedney et al. 2000; Ducharne et al. 1998; Douville

DOI: $10.1175 / J H M 613.1$

(C) 2007 American Meteorological Society 
2003). Soil moisture is considered as an initial value problem for numerical weather forecasting (Pielke et al. 1999; Douville 2004). Soil moisture-atmosphere feedbacks are important in semiarid and temperate climates (Schär et al. 1999) where there is a strong coupling between the land and the atmosphere (Koster et al. 2004).

Most LSMs used in climate modeling calculate radiation, heat, and water exchanges for regional climate model (RCM) or general circulation model (GCM) grids with horizontal grid scales ranging between ten and several hundred kilometers. At these scales soil moisture, rainfall, and runoff are subgrid-scale processes. Small-scale variations in rainfall intensity can produce infiltration excess runoff (Horton runoff). Various techniques for downscaling large-scale rainfall fields exist. Accounting for subgrid-scale rainfall significantly improves runoff from mountainous catchments (Ahrens 2003; Kleinn et al. 2005). Saturation excess runoff (Dunne runoff) occurs where the soil column is sufficiently saturated. Subsurface drainage is important in mountainous terrain: it occurs faster on slopes and is strongly driven by small-scale topographic variability. Similarly, groundwater flow is a lateral flow of soil water in the saturated zone. Flow velocity, however, decreases sharply with dryer soil conditions and with increasing depth. Lateral groundwater flow has characteristic maximum velocities of $0.1-10\left(\mathrm{~m} \mathrm{day}^{-1}\right)$, which is slow compared to surface runoff (both Dunne and Horton runoff). It may however determine the longterm soil moisture conditions by redistribution of soil water within catchments. Various aggregation methods have been suggested to account for the scaling problem of soil moisture and runoff due to topography (Famiglietti and Wood 1991, 1994; Stieglitz et al. 1997; Koster et al. 2000; Walko et al. 2000; Gedney and Cox 2003; Yang and Niu 2003; Niu et al. 2005).

Several model intercomparison studies have explored the representation of hydrological processes in today's LSMs. In the Project for the Intercomparison of Land-Surface Parameterization Schemes 2(c) [PILPS 2(c); Wood et al. 1998; Lohmann et al. 1998; Liang et al. 1998] the ratio between modeled and observed runoff ranged between $13 \%$ and $270 \%$. PILPS 2(e) (Bowling et al. 2003a,b; Nijssen et al. 2003) compared 21 LSMs in a high-latitude catchment and demonstrated that mainly the seasonal distribution of runoff varied among the models. The Rhône Aggregation (Rhône-AGG) experiment (Boone et al. 2004) showed that LSMs simulate very different ratios between surface and drainage runoff, and runoff performance was highly sensitive to this ratio. Furthermore, schemes using subgrid-scale soil moisture better simulated grid-scale run- off since the inclusion of subgrid-scale heterogeneity and topography allows for a better estimation of the surface/drainage runoff ratio. Lohmann et al. (2004) used four LSMs of current climate models and found that streamflow varied by a factor of 4 and differences of snowmelt resulted in spring runoff timing offsets of several months.

The aforementioned uncertainties motivate a process-based study in a catchment with a dense observational network, enabling a thorough analysis of modeled soil moisture and runoff. It is important to know whether subgrid-scale soil moisture processes can be horizontally and vertically aggregated for use in a physically based LSM at RCM and GCM grid scales. Furthermore we should investigate if such aggregation methods are scale dependent. Finally, it is necessary to explore in what climatic regime subgrid-scale soil moisture processes play a role and how they influence the long-term land surface water balance.

To answer the above questions this study follows the mindset of Famiglietti and Wood (1994) and explores the impact of scale and aggregation on modeled soil moisture and runoff. Our focus lies in the analysis of the seasonal and yearly water balance simulated by the LSM Simple Biosphere model version 2.5 ( $\mathrm{SiB} 2.5$; Sellers et al. 1996; Vidale and Stöckli 2005). Such a study requires a high-resolution (in space and time) observational database providing both meteorological driver data and hydrological validation data. We make use of the Rhône-AGG initiative (Boone et al. 2004), which is part of the Global Energy and Water Cycle Experiment (GEWEX). Rhône-AGG provides a framework that can help to better understand scaling issues and uncertainties in LSM hydrology on the seasonal to interannual time scale, as outlined above. The Rhône catchment (Figs. 1a,b) includes climatic zones ranging between Mediterranean (Ardeche), high-altitude Alpine (Durance), and temperate climates (Saône), encompassing flat as well as mountainous areas. The expected weak land-atmosphere coupling in this region (Koster et al. 2004) enables offline (driven and not coupled to the atmosphere) LSM simulations and we also expect a low sensitivity of the turbulent land-atmosphere fluxes to soil moisture processes for this catchment.

We will now describe models and observations. Experiments are then performed at a range of grid scales $\left(8 \mathrm{~km}, 0.5^{\circ}\right.$, and $\left.1^{\circ}\right)$ and using three spatial aggregation methods to account for vertical and horizontal soil moisture variability within large-scale grid cells. We present results from three yr-long offline model integrations over the Rhône catchment. Comparisons between simulated and observed runoff are presented separately for monthly and daily time scales. Scaling 

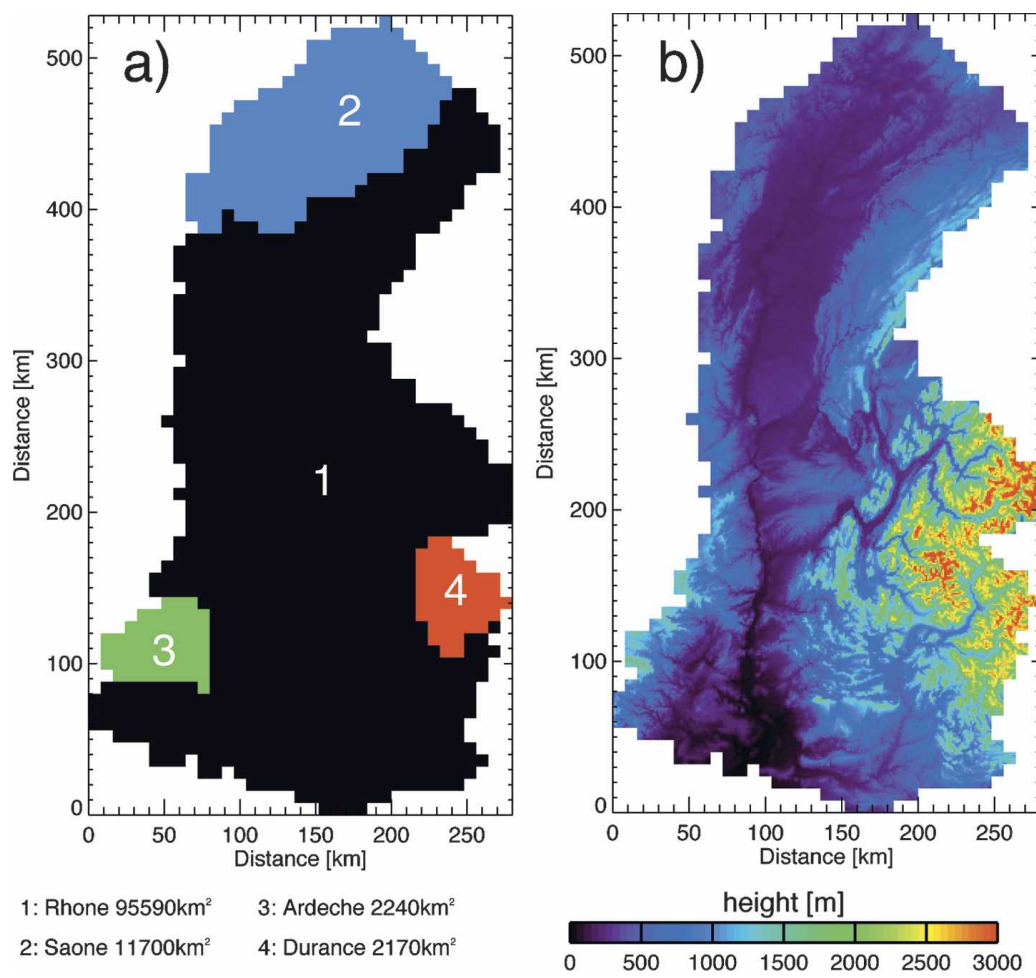

C)

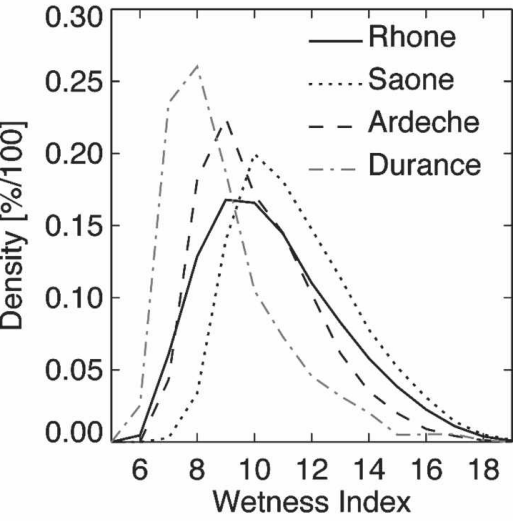

$\begin{array}{ll}\text { 1: Rhone } 95590 \mathrm{~km}^{2} & \text { 3: Ardeche } 2240 \mathrm{~km}^{2} \\ \text { 2: Saone } 11700 \mathrm{~km}^{2} & \text { 4: Durance } 2170 \mathrm{~km}^{2}\end{array}$

FIG. 1. (a) The Rhône (1, including 2, 3, and 4) basin with the Saône (2), Ardeche (3), and Durance (4) subcatchments; (b) the Rhône topography dataset used to derive (c) wetness index distributions.

and aggregation issues are finally discussed by subcatchment, each having its distinct climate regime.

\section{Methods}

\section{a. Model description}

This study employs the land surface model $\mathrm{SiB} 2.5$ by Sellers et al. 1996 and Vidale and Stöckli 2005). SiB 2.5 has been successfully validated over a wide range of spatial and temporal scales in an offline mode by Baker et al. (2003) and Stöckli and Vidale (2005) and in a coupled mode by Denning et al. (2003) and Nicholls et al. (2004). Three different soil moisture schemes (Fig. 2) are realized: the original Sellers et al. (1996) threelayer vertical soil (3L), a new multilayer (ML) soil after Bonan (1996) using a vertical root distribution by Zeng (2001), and the latter including subgrid-scale soil moisture variations (MLTOP) by use of Topmodel (Beven and Kirkby 1979).

All schemes use the same above-ground radiation, heat, water, and carbon exchange formulations. As shown in Fig. 2a bare soil evaporation, $\mathrm{LE}_{G}$, infiltration excess runoff, $R_{\mathrm{IX}}$, and saturation excess runoff, $R_{\mathrm{SX}}$, are simulated as described in Sellers et al. (1996). Soil moisture treatment however differs: $3 \mathrm{~L}$ and $\mathrm{ML}$ allow drainage runoff, $R_{D}$, from the lowest soil layer. $3 \mathrm{~L}$ cal- culates canopy transpiration, $\mathrm{LE}_{C}$, from a single root soil layer (2), controlled by its water content, $S_{2}$. Transpiration, $\mathrm{LE}_{C}$, in $\mathrm{ML}$ (Fig. 2b) is weighted by root fraction, $r_{i}$ (Zeng 2001), of each soil layer, $i$, controlled by water content, $S_{i}$. In MLTOP multiple ML-based patches, $p$, are used within one grid cell (Fig. 2c). An exponential decrease of soil hydraulic conductivity with depth is used to create a groundwater table for each patch. This groundwater table depth, $z_{p}$, is diagnosed by counting saturated soil layers, starting from the bottom layer, L. A rise (lowering) of the groundwater table from its equilibrium state creates a lateral water flux from (to) each patch. Water is conserved within a grid cell and grid-scale drainage runoff, $R_{D}$, occurs from sufficiently saturated soil layers in every patch. The equilibrium water table depends on subgrid-scale topography by use of a time-invariant wetness index $W$, derived from a high-resolution (1-km or better grid scale) topographic dataset. Here $W$ describes the longterm tendency of an area to gain or lose soil water by lateral water fluxes. Topographically convergent areas generally have high $W$ values and their water table is close to the surface. These areas can saturate (wetlands) and can generate saturation excess runoff. Elevated terrain with ridges and peaks has low $W$ values due to high slope angles, which creates a divergent lat- 
a)

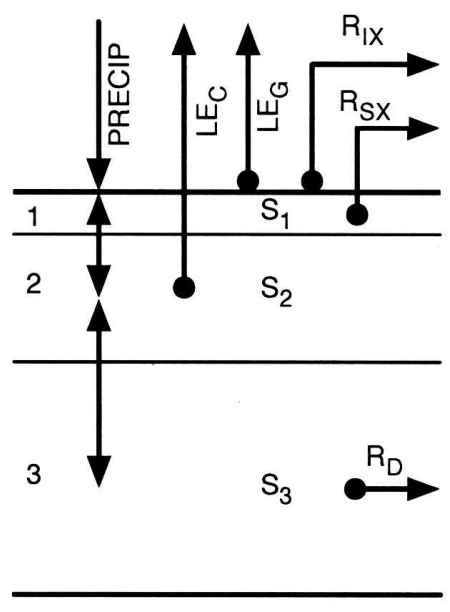

3-Layer b)

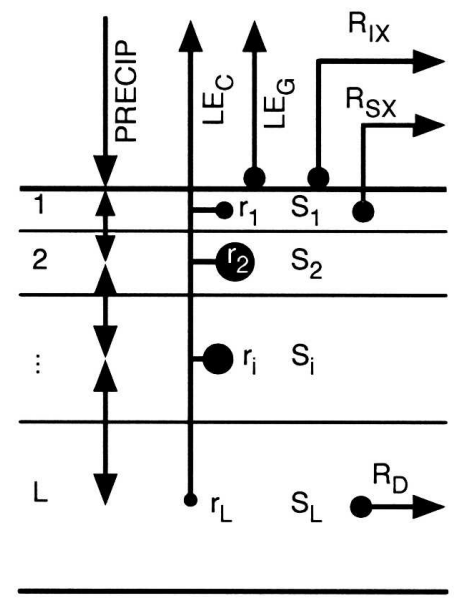

Multi-Layer

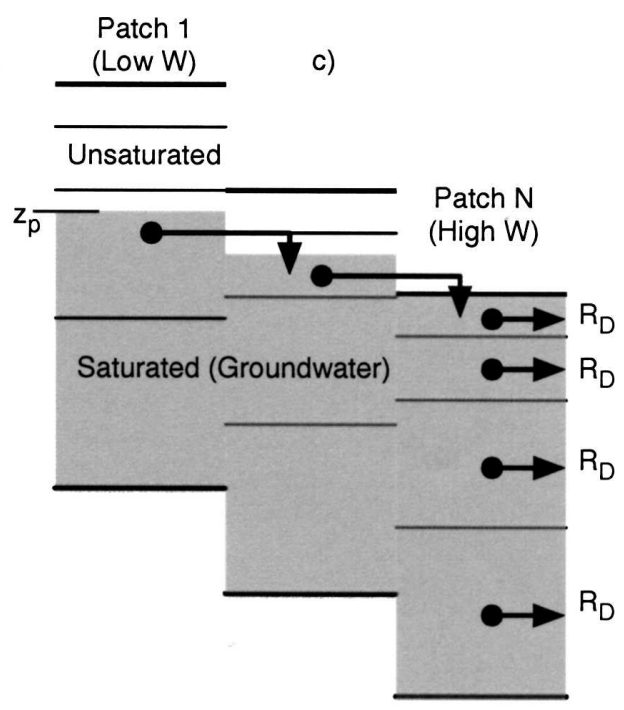

Multi-Layer patches using Topmodel

FIG. 2. Soil moisture schemes used in this study: (a) three-layer (3L), (b) multilayer (ML), and (c) multilayer-Topmodel (MLTOP).

eral drainage flux $R_{D}$ away from these areas. A full description of the employed Topmodel formulation can be found in Walko et al. (2000).

As a summary, we use three standard but different methods of aggregating soil moisture for grid-scale soil columns but we keep all above-ground biophysical processes constant for these schemes. (To understand the difference between the schemes, Fig. 8 may be consulted since it demonstrates the resulting seasonal course of soil moisture for 3L, ML, and MLTOP.)

\section{b. Driver dataset}

$\mathrm{SiB} 2.5$ is forced at reference level $(30 \mathrm{~m})$ with downwelling radiation (shortwave/longwave), wind, temperature, relative humidity, rainfall, and surface pressure provided at an $8-\mathrm{km}$ spatial grid and at a 3-h interval for the Rhône catchment. This dataset is available from the Rhône-AGG initiative (Boone et al. 2004). The SiB 2.5 snowfall parameterization was used (even though Rhône-AGG provides frozen/liquid precipitation). The Hansen et al. (2000) University of Maryland (UMD) land cover map and the FAO (1995) Digital Soil Map of the World were used to derive spatially distributed vegetation and soil parameters according to the standard $\mathrm{SiB} 2.5$ vegetation and soil lookup tables. The Advanced Very High Resolution Radiometer (AVHRR)-based 1982-2001 European Fourieradjusted and interpolated normalized difference vegetation index (NDVI-EFAI) dataset (Stöckli and
Vidale 2004) was used at a 10-day temporal and 8-km spatial resolution to derive time-dependent vegetation parameters. Wetness indices $W$ (Fig. 1c) were derived from the 1-km GTOPO30 dataset (USGS 1996) (Fig. 1b).

\section{c. Validation dataset}

Model results have been validated using observed monthly runoff from the Rhône (size: $95590 \mathrm{~km}^{2}$, mean altitude: $685 \mathrm{~m})$, Saône (11 $\left.700 \mathrm{~km}^{2}, 330 \mathrm{~m}\right)$, Ardeche $\left(2240 \mathrm{~km}^{2}, 677 \mathrm{~m}\right)$ and Durance $\left(2170 \mathrm{~km}^{2}, 2149 \mathrm{~m}\right)$, and daily runoff from the Ain $\left(1251 \mathrm{~km}^{2}, 728 \mathrm{~m}\right)$ and Ognon (2129 km², $332 \mathrm{~m})$ subcatchments as provided by the Rhône-AGG initiative (Fig. 1a; Ain and Ognon not shown). Twenty-four snow depth measurement sites (Boone et al. 2004) are used to compare to modeled snow water equivalent (SWE) of nearest grid cells by use of a snow density (model constant) of $250 \mathrm{~kg} \mathrm{~m}^{-3}$.

\section{d. Experimental setup}

Model integrations for the period August 1985-July 1989 were performed but only the full years 1986, 1987, and 1988 were used for the analysis. The experiments listed in Table 1 allow us to explore the sensitivity of the hydrological cycle to the scale and aggregation of soil moisture and runoff. The original Rhône-AGG forcing data were provided at $8 \mathrm{~km}, 0.5^{\circ}$ (RCM, approximately $50 \mathrm{~km}$ ), and $1^{\circ}$ (GCM, approximately 100 
TABLE 1. Experimental matrix.

\begin{tabular}{llll}
\hline \hline \multirow{2}{*}{ Model } & \multicolumn{3}{c}{ Resolution } \\
\cline { 2 - 4 } \multicolumn{1}{c}{$8 \mathrm{~km}(8 \mathrm{KM})$} & \multicolumn{1}{c}{$0.5^{\circ}(\mathrm{RCM})$} & \multicolumn{1}{c}{$1^{\circ}(\mathrm{GCM})$} \\
\hline 3 layers & $3 \mathrm{~L}-8 \mathrm{KM}$ & $3 \mathrm{~L}-\mathrm{RCM}$ & 3L-GCM \\
12 layers & ML-8KM & ML-RCM & ML-GCM \\
$\begin{array}{c}\text { 12 layers }+ \\
\text { Topmodel }\end{array}$ & MLTOP-8KM & MLTOP-RCM & MLTOP-GCM \\
\hline
\end{tabular}

$\mathrm{km})$ resolutions. For each grid size the predominant soil types, vegetation types, and area-averaged EFAINDVI values were used to create standard $\mathrm{SiB} 2.5$ soil and vegetation parameters, which were not tuned.

The model soil was initialized at $95 \%$ of saturation and at $285 \mathrm{~K}$ with no snow cover on 1 August 1985 and was spun up for $4.5 \mathrm{yr}$. Total soil depth was $5.4 \mathrm{~m}$ for all experiments and all schemes. The $3 \mathrm{~L}$ soil layers were set up as follows: $0.02,1$, and $4.38 \mathrm{~m}$ (the first two being standard in the model). Soil layers in ML and MLTOP were set up with 12 soil layers: 0.1-m top soil with a scaling factor of 1.25 for successive layers: this creates a total soil depth of $5.4 \mathrm{~m}$. MLTOP furthermore divided each grid cell into 10 Topmodel subgrid patches. The only tunable Topmodel parameter, the exponential decay parameter for soil hydraulic conductivity, $f$, was set to $1 \mathrm{~m}^{-1}$.

\section{Results}

\section{a. Impact of scale}

Scale dependency of runoff, snow depth, and surface fluxes is analyzed in this section by using the ML model version forced at different spatial resolutions $(8 \mathrm{~km}$, RCM, and GCM). The observed small-scale variability of rainfall and soil moisture is thought to be a main driver of runoff timing and magnitude.

\section{1) Monthly Runoff AND SuRface FLuXes}

Figure 3 shows observed and simulated monthly runoff (top plots, curves) as well as simulated latent heat fluxes (bottom plots, curves from the bottom up) and plant water stress (bottom plots, curves from the top down) for Rhône, Saône, Ardeche, and Durance.

Simulated Rhône and Saône runoff and LE fluxes are largely scale insensitive. The $R^{2}$ values and runoff ratio (modeled/observed) for ML only decrease slightly from the $8 \mathrm{~km}$ to the GCM grid scale (Table 2). Spring runoff is overestimated and ML is unable to reproduce Rhône autumn runoff (concurrent with the October peak in precipitation; gray bars in Fig. 3a) at all grid scales. ML overestimates spring and summer runoff for Saône, resulting in high runoff ratios of 1.17-1.21. Figure $3 b$ also suggests a time lag of 1-2 months.

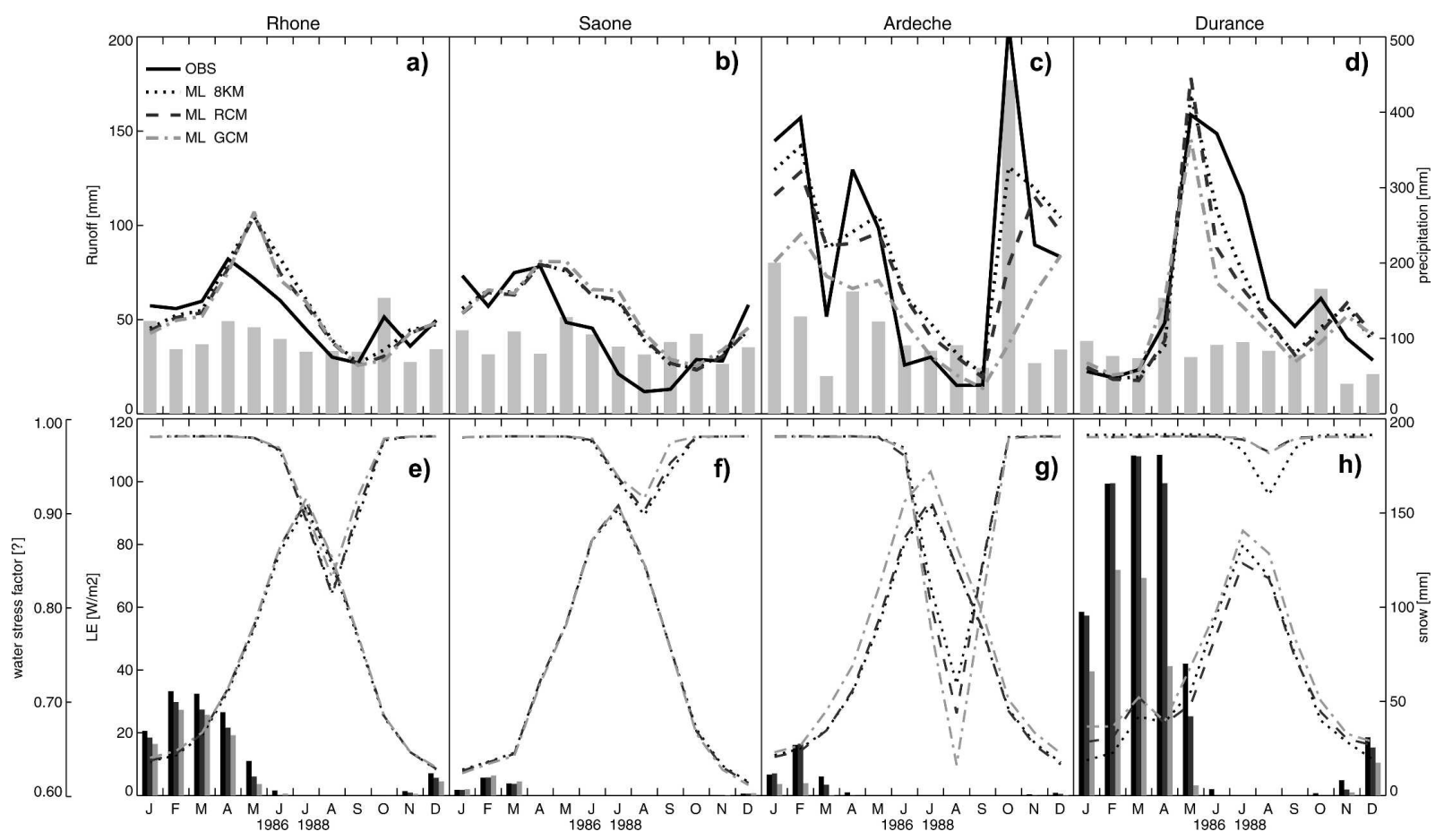

FIG. 3. The impact of grid scale [ $8 \mathrm{~km}, \mathrm{RCM}\left(0.5^{\circ}\right)$, and GCM $\left.\left(1^{\circ}\right)\right]$ on the terrestrial water cycle. (top) Modeled runoff (curves) and (bottom) latent heat flux (curves from the bottom up), plant water stress (curves from the top down), and snow water equivalent (bars) are shown for Rhône, Saône, Ardeche, and Durance, as simulated by ML. Monthly precipitation (from the forcing dataset) is plotted as gray bars in the top plots. 
TABLE 2. Monthly runoff coefficients: $R^{2}$ and the ratio of modeled/observed runoff (in parentheses), 1986-88. (Ardeche observations are 1987-88.)

\begin{tabular}{lccc}
\hline \hline & \multicolumn{3}{c}{ Resolution } \\
\cline { 2 - 4 } Model & $8 \mathrm{~km}(8 \mathrm{KM})$ & $0.5^{\circ}(\mathrm{RCM})$ & $1^{\circ}(\mathrm{GCM})$ \\
\hline 3L & $0.57(1.09)$ & $0.55(1.02)$ & $0.50(1.00)$ \\
ML & $0.75(1.07)$ & $0.72(1.03)$ & $0.68(1.02)$ \\
MLTOP & $0.94(1.10)$ & $0.94(1.09)$ & $0.94(1.06)$ \\
3L & $0.42(1.17)$ & $0.34(1.11)$ & $0.33(1.16)$ \\
ML & $0.56(1.17)$ & $0.52(1.16)$ & $0.47(1.21)$ \\
MLTOP & $0.95(1.20)$ & $0.93(1.20)$ & $0.91(1.23)$ \\
3L & $0.94(1.02)$ & $0.82(0.90)$ & $0.72(0.61)$ \\
ML & $0.86(1.03)$ & $0.74(0.92)$ & $0.58(0.65)$ \\
MLTOP & $0.96(1.03)$ & $0.97(0.90)$ & $0.98(0.65)$ \\
3L & $0.94(0.90)$ & $0.83(0.82)$ & $0.76(0.77)$ \\
ML & $0.92(0.87)$ & $0.87(0.85)$ & $0.81(0.78)$ \\
MLTOP & $0.77(0.88)$ & $0.65(0.91)$ & $0.29(0.84)$ \\
\hline
\end{tabular}

Ardeche runoff peaks in spring and late autumn caused by precipitation variability. At GCM grid-scale $R^{2}$ and runoff ratio decrease while LE is enhanced by $15 \%$ compared to the $8-\mathrm{km}$ simulation. This results in a lower root soil-moisture content, shown by the plant water stress factor (1: unstressed vegetation; 0 : wilting condition). This coincides with a lower and more realistic summer baseflow (due to higher LE) simulated at GCM grid scale. However, at higher spatial resolutions the magnitude and timing of spring and autumn runoff peaks are better simulated: small-scale rainfall intensity can be resolved, which then results in more intense runoff.

Observed Durance runoff peaks in late spring and is low during the rest of the year. Since precipitation is rather uniformly distributed throughout the year (Fig. $3 \mathrm{~d}$, gray bars), runoff must be driven by late spring snowmelt. ML simulates both magnitude and the onset of snowmelt runoff well, but underestimates its duration. Catchment-average snow water equivalent raises to almost $175 \mathrm{~cm}$ (Fig. 3h) and is scale dependent. As a consequence spring runoff duration decreases substantially with increasing grid scales. Scale dependence of modeled snow is also displayed in Fig. 4, where snow depths - as measured at 24 mountain sites-are compared to modeled snow depth (nearest grid point). The 8-km grid-scale matches well and shows a low RMS and bias (Table 3), while differences grow toward the GCM grid scale. Snow accumulation is still comparable to observations at the RCM grid scale but snowmelt happens 1.5 months too early. At the GCM grid scale the evolution of snow depth in this Alpine subcatchment cannot be reproduced, which obviously affects the simulated snowmelt runoff and is consistent with results in Boone et al. (2004).

\section{2) DAILY RUNOFF}

Analysis of daily runoff gives insight to modeled streamflow response to individual rainfall events and of the baseflow between such events. In Fig. 5 observed and simulated runoff is shown for the Ain subcatchment during 1987. It demonstrates that ML cannot resolve runoff at the daily time scale. It severely underestimates runoff response to rainfall events and on the other hand it overestimates baseflow at all applied scales. However, higher magnitudes and a better response timing result from the use of smaller grid scales (e.g., after the extended June 1987 rainfall event). The $R^{2}$ and the Nash-Sutcliffe efficiency criterion (Table 4) show a steadily increasing daily runoff prediction skill with decreasing grid scale.

\section{b. Impact of aggregation}

Soil moisture is highly variable on small scales, as described in the introduction, and runoff can be sensi-
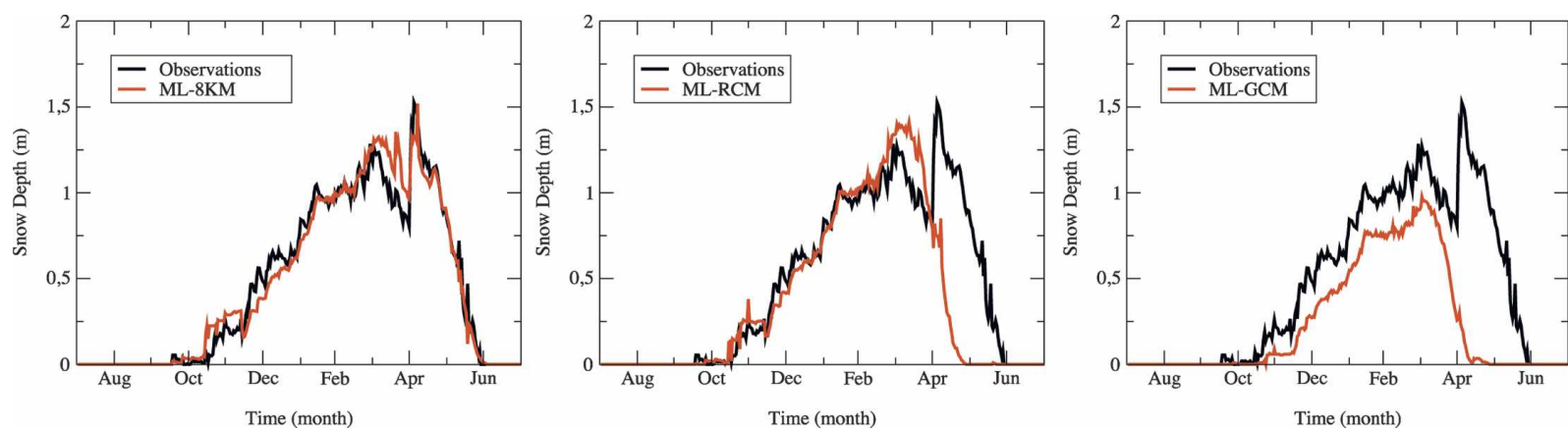

FIG. 4. Scale dependence of modeled snow: snow depth comparison for 24 snow observation sites with snow depth simulated by ML at the 8-km, RCM, and GCM grid scales (1986-88). 
TABLE 3. Scale dependence of modeled snow: ML snow (forced at $8-\mathrm{km}, \mathrm{RCM}$, and GCM grid scales) compared to snow observations (1986-88).

\begin{tabular}{cccc}
\hline \hline Resolution & RMS $(\mathrm{m})$ & $R^{2}$ & Bias $(\mathrm{m})$ \\
\hline 8KM & 0.34 & 0.73 & 0.00 \\
RCM & 0.55 & 0.42 & 0.03 \\
GCM & 0.51 & 0.47 & -0.24 \\
\hline
\end{tabular}

tive to the spatial resolution of the LSM and its forcing data, as seen in the previous section. Therefore spatial soil moisture aggregation methods for use at RCM and GCM grid scales may help to overcome scaling issues of soil moisture. We investigate the effect of spatial soil moisture aggregation on simulated evapotranspiration and runoff by use of the three above-described aggregation methods: ML differs from $3 \mathrm{~L}$ by better resolving the vertical transfer of soil moisture within a grid cell. MLTOP differs from ML by furthermore resolving horizontal variability of soil moisture due to the use of subgrid-scale topography within a grid cell.

\section{1) Monthly Runoff And surface fluXes}

Figure 6 shows monthly runoff (top plots, curves), latent heat fluxes (bottom plots, curves from the bottom up), and plant water stress (bottom plots, curves from the top down) simulated by $3 \mathrm{~L}, \mathrm{ML}$, and MLTOP at the RCM grid scale. Modeled runoff is compared to observed runoff for Rhône, Saône, Ardeche, and Durance.

For Rhône and Saône 3L simulates too little winter runoff and on the other hand overestimates summer runoff. The spring runoff peaks are overestimated by ML and it shows a delayed response in spring runoff. From Table 2 (Rhône catchment) it can be seen that the use of a multilayer soil scheme (ML) instead of a three-layer soil scheme (3L) increases the $R^{2}$ of monthly runoff from 0.55 to 0.72 . The use of Topmodel (MLTOP) further increases $R^{2}$ to 0.94. For Saône 3L has a rather low $R^{2}$ value of 0.34 . ML is able to capture the seasonal cycle but shows a delay of about 2 months $\left(R^{2}=0.52\right)$. MLTOP captures both timing and magnitude of the seasonal cycle at both catchments, slightly overestimating summer runoff for Saône $\left(R^{2}\right.$ of 0.95 at 8-km grid scale and 0.91 at GCM grid scale).

All three models have skill in capturing the seasonal course of Ardeche runoff. Summer baseflow is however largely overestimated by $3 \mathrm{~L}\left(R^{2}=0.82\right)$ at $\mathrm{RCM}$ grid scale and somewhat by ML $\left(R^{2}=0.74\right)$, but not by $\operatorname{MLTOP}\left(R^{2}=0.97\right)$. The opposite happens in autumn: MLTOP matches the high magnitude of observed October runoff-which is mainly driven by local-scale convective precipitation-while $3 \mathrm{~L}$ and $\mathrm{ML}$ are much lower. Figure $6 \mathrm{c}$ shows that ML runoff for Ardeche is delayed from the observed (and 3L) runoff. LE fluxes do not change with aggregation method, except at GCM grid scale, where both ML and MLTOP show about $8 \%-10 \%$ higher mean LE than $3 \mathrm{~L}$. As shown above Ardeche vegetation is soil moisture stressed in summer, and the parameterized vertical root distribution used in ML and MLTOP seems to have less sensitivity to drought conditions than the single 1-m-deep root layer in 3L.

Monthly Durance runoff is best captured by $3 \mathrm{~L}$ and ML. Other than for Rhône, Saône and Ardeche Topmodel (MLTOP) performs worst; $R^{2}$ decreases from 0.83 (3L-RCM) and 0.87 (ML-RCM) to 0.65 (MLTOPRCM). One can see from Fig. $6 \mathrm{~h}$ that both timing and magnitude of snowmelt runoff at Durance are sensitive to aggregation method. $3 \mathrm{~L}$ underestimates the runoff peak in late spring while it matches summer and autumn runoff in both timing and magnitude. ML captures the start of snowmelt runoff but underestimates

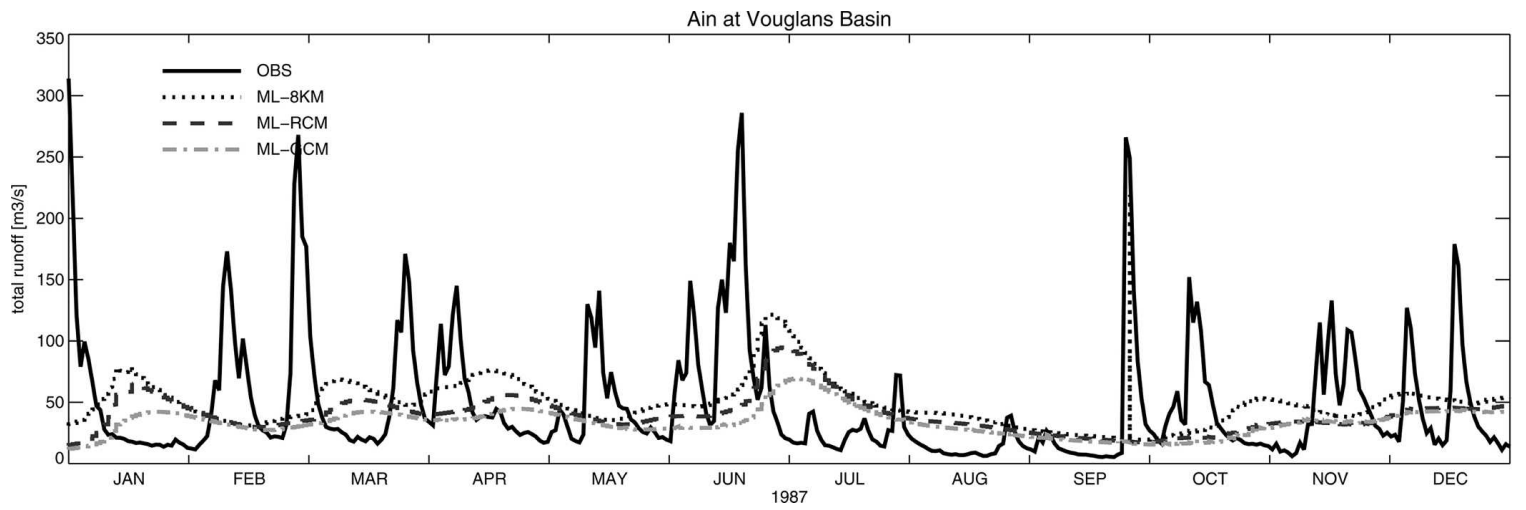

FIG. 5. Impact of scale on modeled daily runoff at the $8-\mathrm{km}$, RCM, and GCM grid scale compared to daily observations from the Ain subcatchment. 
TABLE 4. Daily runoff coefficients: $R^{2}$ and the Nash-Sutcliffe efficiency N (in parentheses), 1986-88.

\begin{tabular}{|c|c|c|c|}
\hline \multirow[b]{2}{*}{ Model } & \multicolumn{3}{|c|}{ Resolution } \\
\hline & $8 \mathrm{~km}(8 \mathrm{KM})$ & $0.5^{\circ}(\mathrm{RCM})$ & $1^{\circ}(\mathrm{GCM})$ \\
\hline \multicolumn{4}{|c|}{ Ain } \\
\hline $3 \mathrm{~L}$ & $0.29(0.05)$ & $0.21(-0.02)$ & $0.16(-0.08)$ \\
\hline ML & $0.13(-0.14)$ & $0.11(-0.15)$ & $0.11(-0.16)$ \\
\hline MLTOP & $0.61(0.34)$ & $0.70(0.37)$ & $0.66(0.22)$ \\
\hline \multicolumn{4}{|c|}{ Ognon } \\
\hline $3 \mathrm{~L}$ & $0.42(0.10)$ & $0.36(0.07)$ & $0.36(0.04)$ \\
\hline ML & $0.25(-0.18)$ & $0.18(-0.32)$ & $0.14(-0.39)$ \\
\hline MLTOP & $0.86(0.69)$ & $0.88(0.66)$ & $0.87(0.64)$ \\
\hline
\end{tabular}

its duration. It simulates a 1-month delay in autumn runoff-a distinct feature of this particular scheme, which already showed up in the other catchments. MLTOP predicts snowmelt runoff early by one month and also underestimates its duration. It also shows a too-low summer baseflow. MLTOP then simulates excessive autumn runoff, although its timing is precise.

\section{2) DAILY RUNOFF}

In Fig. 7 daily observed runoff (Ain subcatchment, 1987) and simulated runoff by $3 \mathrm{~L}, \mathrm{ML}$, and MLTOP are shown. 3L runoff does not respond to individual rainfall events-except for a few spikes (e.g., end of August) that are due to $3 \mathrm{~L}$ infiltration excess runoff. ${ }^{1} \mathrm{ML}$ is responsive to the major rainfall events, but its runoff is delayed by about half a month. Because of this delay $R^{2}$ coefficients and Nash-Sutcliffe efficiency criterion both decrease from 3L to ML (Table 4) at all grid scales, which was already seen for Ardeche. Generally, baseflow is overestimated and runoff peaks are severely underestimated by both 3L and ML, but not by MLTOP. The use of subgrid-scale topography in MLTOP allows one to capture fast runoff responses after rainfall events quite precisely, as shown in Fig. 7. The correct estimation of magnitude and temporal response of such runoff events also results in a much better estimation of baseflow from groundwater recharge.

\section{c. Surface runoff}

The models produced very little surface runoff (less than $20 \mathrm{~mm}$ per year). Infiltration excess runoff is mainly triggered by convective rainfall. $\mathrm{SiB} 2.5$ is able to account for convective rainfall (Sellers et al. 1996) but Rhône-AGG driver fields did not include separate

\footnotetext{
${ }^{1}$ All models have the same infiltration excess parameterization, but $3 \mathrm{~L}$ only has a $2-\mathrm{cm}$ top soil layer, which is more sensitive to this type of runoff than the $10-\mathrm{cm}$ top soil layers of ML and MLTOP.
}

convective and large-scale rainfall. Saturation excess runoff was below $0.1 \mathrm{~mm}$ per month since surface layers almost never saturated in the analyzed catchments. As a feature MLTOP could however generate substantial saturation excess runoff for wetland areas where the water table is close to the surface.

\section{Discussion}

\section{a. Rhône and Saône: Scaling of soil moisture and runoff}

3L and ML runoff for Rhône and Saône has a moderate scale dependency. MLTOP on the other hand shows an approximately scale-independent $R^{2}(0.9$ or higher for $8 \mathrm{~km}, \mathrm{RCM}$, and GCM). Runoff ratios, LE, and thus the annual water balance are neither sensitive to scaling nor to aggregation method. The parameterization of runoff by the models used in this study therefore has little feedback on the long-term terrestrial water balance for Rhône and Saône. The analyzed water stress factor also shows that evapotranspiration is not soil moisture limited in the aforementioned basins, which also infers a weak land-atmosphere coupling in this area (Koster et al. 2004). Evapotranspiration is therefore controlling runoff as the residual of the water balance and not vice-versa. Still, the seasonal course of runoff differs substantially between $3 \mathrm{~L}$, ML, and MLTOP. Especially the use of Topmodel better captures timing and magnitude of spring and autumn runoff peaks, resulting in a lower (and more realistic) summer baseflow.

The vertical resolution of soil biophysical processes influences soil moisture dynamics and therefore runoff. The temporal evolution of the modeled Rhône soil moisture profiles (Fig. 8) helps to explain this connection: The second layer in 3L shows high fluctuation due to transpiration and infiltration. The drainage layer however has little variability. A drying of the root layer in $3 \mathrm{~L}$ inhibits the water flux from the root layer to the third layer (and therefore drainage) since-as the soil dries-hydraulic conductivity $K$ decreases rapidly (Fig. 9). Transpiration controls runoff but not vice-versa since transpiration is only limited at very low soil moisture levels (plant water stress curve in Fig. 9). In ML transpiration is weighted by a vertical root distribution and plants have a limited access to soil water below a certain depth (dependent on vegetation type). This results in a faster vertical soil moisture transfer and in higher runoff peaks (Fig. 8, bottom graph). But on the other hand ML runoff is delayed since it misses an important hydrological process: lateral drainage caused by topography. This process is included in MLTOP and results in fast drainage from saturated soil layers after a 

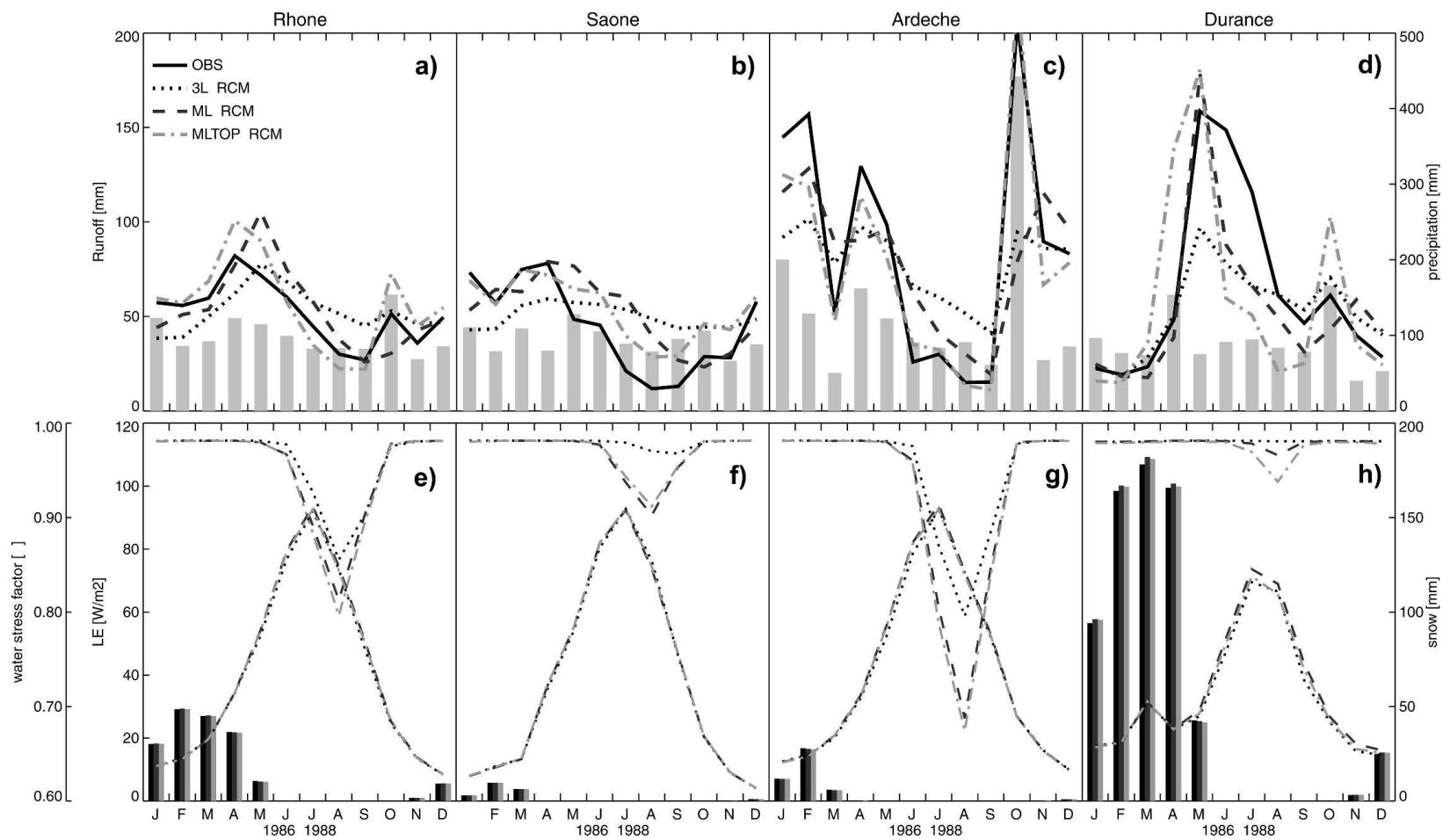

FIG. 6. The impact of the three different soil moisture aggregation methods 3L, ML, and MLTOP on the terrestrial water fluxes when forced at RCM grid scale. (top) Monthly modeled runoff (curves) and (bottom) latent heat flux (curves from the bottom up), plant water stress (curves from the top down), and snow water equivalent (bars) are shown for Rhône, Saône, Ardeche, and Durance. Monthly precipitation (from the forcing dataset) is plotted as gray bars in the top plots.

rainfall event and at the same time refills the groundwater table on seasonal time scales (as visible in Fig. 8: third profile). MLTOP closely matches daily runoff peaks and baseflow (e.g., for Ain and Ognon; Table 4 and Fig. 7).

These findings demonstrate that there is a delicate balance between the ability of a scheme to allow water storage on a seasonal time scale in the deep soil, losing it through lateral flow in response to rainfall events and extracting it from the soil for transpiration. All these processes and their interplay need to be included in an LSM to correctly represent the seasonal course of terrestrial water storage (TWS). Hirschi et al. (2006) for instance analyzed the long-term TWS for a number of catchments and found that the seasonal magnitude of water storage varied considerably between 50 and 350 $\mathrm{mm}$ depending on the climatic environment. For the time period of this study (1986-88) the TWS over

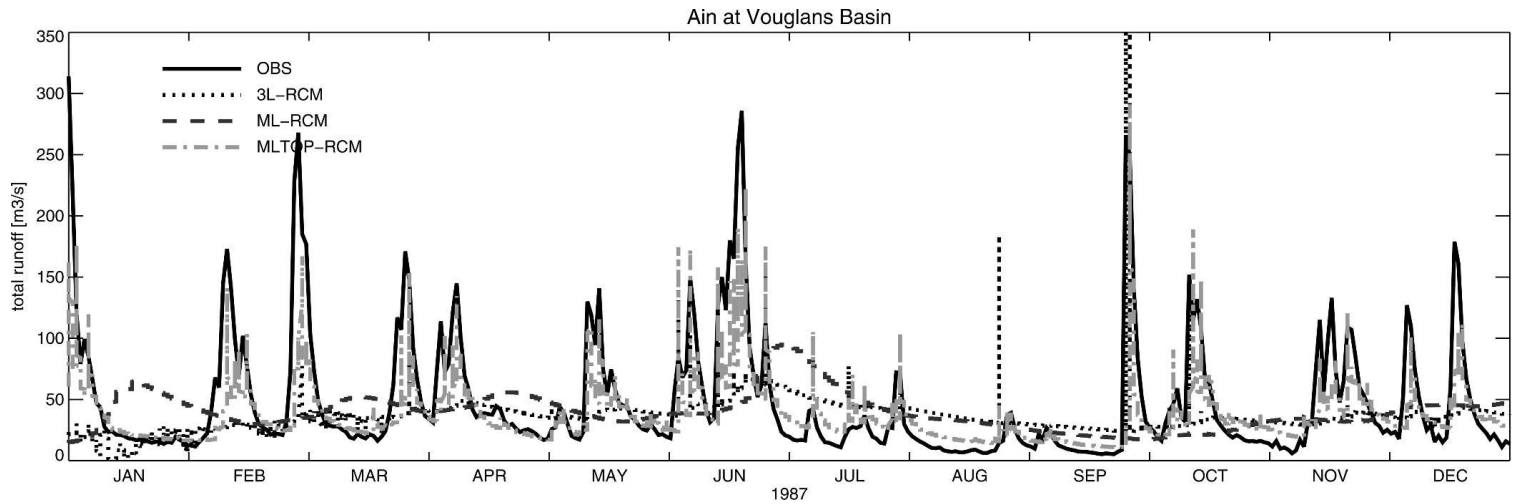

FIG. 7. Impact of aggregation on daily runoff: $3 \mathrm{~L}$, ML, and MLTOP (forced at RCM grid scale) runoff is compared to observed runoff from the Ain subcatchment. 


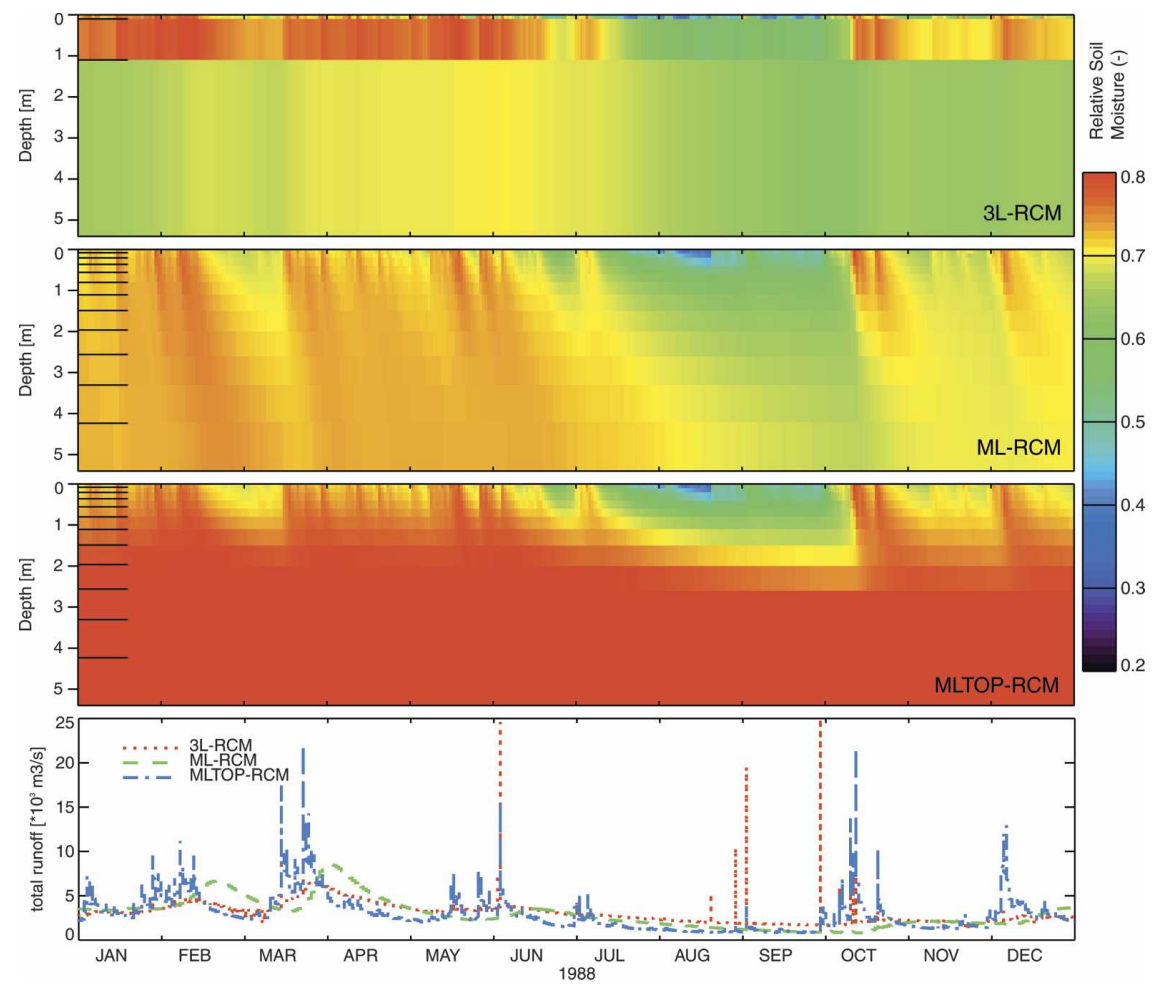

FIG. 8. Modeled vertical soil moisture profiles and runoff at the RCM grid scale, averaged over the whole Rhône catchment (1988). The figure visualizes the impact of the spatial soil moisture aggregation methods $3 \mathrm{~L}$, ML, and MLTOP (Fig. 2) on the seasonal course of soil moisture and runoff. Depths of model layers are shown as ticks on the left part of each plot.

Rhône is 148 mm (M. Hirschi 2005, personal communication). TWS for the $3 \mathrm{~L}$ model is $161 \mathrm{~mm}$; it has too much water storage capacity in the single deep drainage layer where there are no roots. This results in a shallow runoff response and too much summer baseflow. ML has an even higher TWS range of $228 \mathrm{~mm}$ while MLTOP matches diagnosed TWS well with $150 \mathrm{~mm}$. According to Fig. $8 \mathrm{ML}$ is able to regulate the vertical soil water transfer but does not include the groundwater storage, which acts as a buffer in MLTOP. In more arid climate zones with seasonal drought periods this buffer might actually help to increase TWS magnitude since water stored in the deep soil during the wet season can be reused during the dry season and is not lost to grid-scale drainage.

\section{b. Ardeche: Scaling of rainfall and runoff}

For Ardeche we find higher LE and less runoff at larger grid scales; the terrestrial water balance is scale dependent. This result is consistent with findings by Boone et al. (2004). The scale dependency in modeled LE can be explained with its nonlinear dependency on radiation and temperature (Boone et al. 2004), since these variables are averaged at larger grid scales.
Higher LE results in lower root soil moisture. Therefore the modeled plant water stress is more severe at larger grid scales, reducing summer baseflow (Fig. 3c).

As for Rhône and Saône, evapotranspiration seems to determine the total water available for runoff. Its seasonal course on the other hand considerably differs by aggregation method and by grid scale. MLTOP shows a better performance than $3 \mathrm{~L}$ and ML, the latter two underestimating the runoff peaks in spring and autumn. The analysis also shows that ML, for instance, performs much better at higher spatial resolutions, while MLTOP seems to be invariant to grid scale. Ardeche rainfall is mainly convective and scale dependency of runoff may be related to scale dependency of rainfall intensity (e.g., Ahrens 2003). These results however suggest that Topmodel offers a spatial aggregation method that largely compensates for the generally observed scale dependency of rainfall-runoff processes. Given that grid-scale precipitation occurs within the simulated catchment, MLTOP redistributes runoff by use of subgrid-scale topography, but only a higher spatial resolution of rainfall can reproduce the fine spatial soil moisture-runoff dynamics in the simpler $3 \mathrm{~L}$ and ML schemes. 


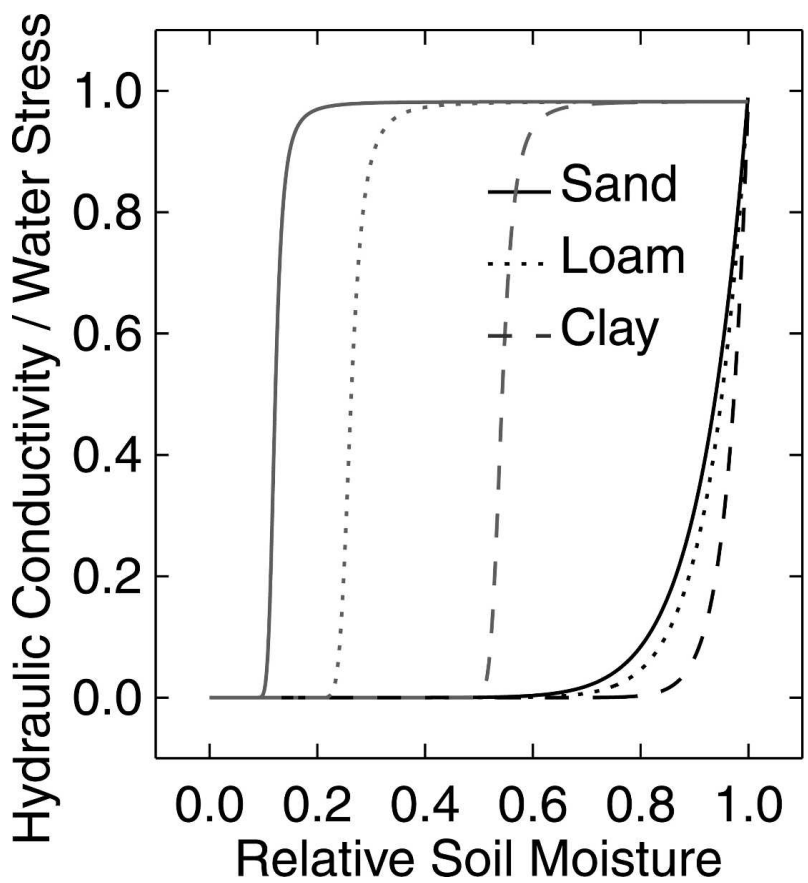

FIG. 9. Sensitivity of modeled hydraulic conductivity (black) and transpiration water stress factor (gray) to soil moisture content for different soil types. Soil moisture is plotted as a fraction relative to saturation values. The water stress factor is 1 when vegetation has sufficient soil water supply and drops to 0 at wilting conditions.

\section{c. Durance: Scaling of snow and runoff}

From previous results we find that MLTOP better captures the course of monthly runoff than the other two schemes. Magnitude of summer baseflow and timing of spring runoff were especially improved compared to $3 \mathrm{~L}$ and ML. Also, daily runoff comparisons show that $R^{2}$ and Nash-Sutcliffe efficiency coefficients are largely scale insensitive for MLTOP. This does not hold in Durance, where snow processes can be significant. There, MLTOP performs worst: at GCM grid scale its $R^{2}$ drops to 0.29 .

Although snow accumulation and snowmelt is scale dependent it does not change between model versions (Fig. 6h, gray bars; average snow values are shown in Table 5) since all of them use the same physical snow scheme. Therefore differences in snowmelt are only due to scaling effects. Larger grid scales have an early and less intense snowmelt, which-by use of topographically driven runoff in MLTOP-leads to an earlier snowmelt runoff as shown in Fig. 6d. 3L and ML with their generally delayed runoff (and not using subgrid-scale topography) compensate the scale dependency of snowmelt and match the observed runoff at Durance much better than MLTOP. These results are in accordance with findings by Boone et al. (2004).
TABLE 5. Mean monthly LE fluxes and snow (in parentheses; $\mathrm{mm}), 1986-88$

\begin{tabular}{|c|c|c|c|}
\hline \multirow[b]{2}{*}{ Model } & \multicolumn{3}{|c|}{ Resolution } \\
\hline & $8 \mathrm{~km}(8 \mathrm{KM})$ & $0.5^{\circ}(\mathrm{RCM})$ & $1^{\circ}(\mathrm{GCM})$ \\
\hline \multicolumn{4}{|c|}{ Rhône } \\
\hline $3 \mathrm{~L}$ & $40.0(18.7)$ & $41.1(15.2)$ & $41.3(13.5)$ \\
\hline ML & $41.2(18.7)$ & $42.0(15.2)$ & $42.5(13.6)$ \\
\hline MLTOP & $40.5(18.6)$ & $41.9(15.1)$ & $42.1(13.5)$ \\
\hline \multicolumn{4}{|c|}{ Saône } \\
\hline $3 \mathrm{~L}$ & $39.6(1.7)$ & $39.6(1.7)$ & $39.0(1.9)$ \\
\hline ML & $39.7(1.7)$ & $39.7(1.7)$ & $39.1(1.9)$ \\
\hline MLTOP & $39.5(1.7)$ & $39.9(1.7)$ & $39.3(1.9)$ \\
\hline \multicolumn{4}{|c|}{ Ardeche } \\
\hline $3 \mathrm{~L}$ & 41.9 (4.4) & $42.2(3.9)$ & $45.3(1.2)$ \\
\hline ML & $42.9(4.4)$ & $43.2(3.9)$ & $49.4(1.2)$ \\
\hline MLTOP & $41.9(4.3)$ & $42.7(3.9)$ & $48.8(1.2)$ \\
\hline \multicolumn{4}{|c|}{ Durance } \\
\hline $3 \mathrm{~L}$ & $33.9(61.6)$ & $34.7(56.1)$ & $39.2(31.8)$ \\
\hline ML & $36.2(61.5)$ & $36.7(57.1)$ & $42.0(32.9)$ \\
\hline MLTOP & $35.7(61.4)$ & $35.5(56.7)$ & $40.5(32.5)$ \\
\hline
\end{tabular}

They also show that the use of an explicit multilayer subgrid-scale snow scheme (which also allows for refreezing of melted snow, not included in SiB 2.5) will help to better match the total snowmelt discharge volume than was achieved in our simulations (A. Boone 2006, personal communication).

\section{Conclusions}

This study explored the influence of scaling and aggregation on the seasonal course of soil moisture and runoff by conducting offline modeling experiments over Rhône. Integration of catchment-scale observations covering a wide range of climatic conditions allowed a process-based evaluation of modeled terrestrial water exchanges.

While neither total cumulated runoff nor surface fluxes are sensitive to soil moisture aggregation scheme over Rhône, the seasonal course of runoff differs substantially between 3L, ML, and MLTOP. The three schemes all have a different way of storing and releasing soil moisture throughout the seasonal course. A temperate catchment like Rhône has a shallow TWS (Hirschi et al. 2006), which was best reproduced by MLTOP: TWS for Rhône is determined by fast topography-driven drainage runoff and a seasonal groundwater recharge acting as a buffer to dampen the TWS. Evapotranspiration and runoff are competing processes for soil moisture and thus the correct representation of both processes is important to model the terrestrial water cycle. While vertical and horizontal distribution of soil moisture has a substantial effect on runoff, evapotranspiration showed very little sensitivity. This result 
was explained by the very high nonlinear dependence of the hydraulic conductivity but weak dependence of plant water stress on soil moisture, given the availability of sufficient soil moisture. Rhône evapotranspiration controls runoff as a residual of the terrestrial water balance. Based on this result it can be hypothesized that the large variability in LSM evapotranspiration-torunoff ratios as seen by model intercomparison projects such as PILPS 2(c) (Wood et al. 1998; Lohmann et al. 1998; Liang et al. 1998) may be mainly due to the difference in evapotranspiration schemes rather than due to the difference in runoff schemes. This finding cannot be generalized but may apply to a large number of catchments in temperate to high-latitude climates. This result is also in accordance with findings by Koster et al. (2004) as hypothesized earlier, where weak land-atmosphere coupling was found for central Europe. With the expected increase in temperature and rainfall variability in a future climate the Mediterranean part of the Rhône could however become susceptible to higher soil moisture variations and therefore develop a stronger coupling (Seneviratne et al. 2006).

Daily analyses showed that hydrologic processes governing magnitude and timing of daily streamflow largely determine monthly means: use of subgrid-scale topography allows one to both capture the seasonal course of groundwater depth (and therefore summer baseflow) as well as daily response of topographydriven runoff in mountainous terrain. Lateral runoff processes that are responsible for both types of runoff cannot be resolved at grid scales of current atmospheric models without the use of subgrid-scale soil moisture. But their relevance, as found in this study, is in accordance with findings from studies using spatially resolved hydrological models (e.g., Gurtz et al. 2003). MLTOP allows one to integrate topographically driven runoff in grid-scale LSMs by use of a statistical formulation of subgrid-scale lateral soil water fluxes. Such a formulation is largely invariant to the used grid scale. However, we know that the spatial scale of convective rainfall (Ahrens 2003) is closely related to spatial variability of soil moisture dynamics (Albertson and Montaldo 2003) as found for the Ardeche. This needs further attention: a study including an integrated analysis of both effects would be beneficial for evaluating process-based hydrological modeling in climate research.

The analysis of snowmelt runoff revealed another level of complexity in grid-scale hydrological processes: results from Durance demonstrate that a good runoff timing does not necessarily have be due to a correct and physically based representation of soil moisture. Runoff simulated by a simpler soil moisture scheme (3L and ML) obscures scaling effects of snowmelt. Use of sub- grid-scale topography (MLTOP) on the other hand produces runoff that is much more sensitive to Alpine snowmelt. This model then shows a bad performance on larger grid scales since snow accumulation and melt cannot be well simulated at RCM and GCM grid scales. As presented in Boone et al. (2004), the one scheme using a spatially resolved subgrid-scale and explicit parameterization of temperature and snow showed the least impact of scaling on simulated snow depth and runoff. A similar performance may be achieved for large grid scales of climate models by using a statistically based subgrid-scale soil moisture scheme (such as MLTOP) with a subgrid-scale snow parameterization.

Acknowledgments. Funding for this study was provided by the National Centre of Competence in Research on climate variability, predictability, and climate risks (NCCR) funded by the Swiss National Science Foundation (NSF) and by NASA Contract NAS501070, Task 4a, and SSAI Subcontract 2101-03-002. The support of the ETH Institute for Atmospheric and Climate Science is gratefully acknowledged. We thank Dr. Habil. Achim Gurtz for his careful review and useful comments. Thanks to Martin Hirschi for the ERA-40 derived TWS data. Thanks to Florence Habets for additional Rhône-AGG data. Thanks to Scott Denning and his research group from Colorado State University for the permission to use $\mathrm{SiB} 2$ and Mapper.

\section{REFERENCES}

Ahrens, B., 2003: Rainfall downscaling in an alpine watershed applying a multiresolution approach. J. Geophys. Res., 108, 8388, doi:10.1029/2001JD001485.

Albertson, J. D., and N. Montaldo, 2003: Temporal dynamics of soil moisture variability: 1 . Theoretical basis. Water Resour. Res., 39, 1274, doi:10.1029/2002WR001616.

Baker, I., A. S. Denning, N. Hanan, L. Prihodko, M. Uliasz, P. L. Vidale, K. Davis, and P. Bakwin, 2003: Simulated and observed fluxes of sensible and latent heat and $\mathrm{CO} 2$ at the WLEF-TV tower using SiB2.5. Global Change Biol., 9, 12621277.

Beven, K. J., and M. J. Kirkby, 1979: A physically based, variable contributing area model of basin hydrology. Hydrol. Sci. Bull., 24, 43-69.

Bonan, G. B., 1996: A land surface model (LSM version 1.0) for ecological, hydrological, and atmospheric studies: Technical description and user's guide. NCAR Tech. Note NCAR/TN417+STR, 122 pp.

Boone, A., and Coauthors, 2004: The Rhône-Aggregation Land Surface Scheme intercomparison project: An overview. $J$. Climate, 17, 187-208.

Bowling, L. C., and Coauthors, 2003a: Simulation of high-latitude hydrological processes in the Torne-Kalix basin: PILPS phase 2(e) -1: Experiment description and summary intercomparisons. Global Planet. Change, 38, 1-30.

_ D. P. Lettenmaier, B. Nijssen, J. Polcher, R. D. Koster, and D. Lohmann, 2003b: Simulation of high-latitude hydrological 
processes in the Torne-Kalix basin: PILPS phase 2(e)-3: Equivalent model representation and sensitivity experiments. Global Planet. Change, 38, 55-71.

Denning, A. S., M. Nicholls, L. Prihodko, I. Baker, P. L. Vidale, K. Davis, and P. Bakwin, 2003: Simulated variations in atmospheric $\mathrm{CO} 2$ over a Wisconsin forest using a coupled ecosystem-atmosphere model. Global Change Biol., 9, 1241-1250.

Dickinson, R. E., 2001: Linking ground hydrology to ecosystems and carbon cycle in a climate model. Present and Future of Modeling Global Environmental Change: Toward Integrated Modeling, T. Matsuno and H. Kida, Eds., Terra Scientific, 137-144.

Douville, H., 2003: Assessing the influence of soil moisture on seasonal climate variability with AGCMs. J. Hydrometeor., 4, 1044-1066.

— - 2004: Relevance of soil moisture for seasonal atmospheric predictions: Is it an initial value problem? Climate Dyn., 22, 429-446.

Ducharne, A., K. Laval, and J. Polcher, 1998: Sensitivity of the hydrological cycle to the parameterization of soil hydrology in a GCM. Climate Dyn., 14, 307-327.

Famiglietti, J. S., and E. F. Wood, 1991: Evapotranspiration and runoff from large land areas: Land surface hydrology for atmospheric general circulation models. Surv. Geophys., 12, 179-204.

—_, and — 1994: Multiscale modeling of spatially variable water and energy balance processes. Water Resour. Res., 30, 3061-3078.

FAO, 1995: Digital Soil Map of the World, Version 3.5. Food and Agriculture Organization of the United Nations, Rome, Italy, CD-ROM.

Gedney, N., and P. M. Cox, 2003: The sensitivity of global climate model simulations to the representation of soil moisture heterogeneity. J. Hydrometeor., 4, 1265-1275.

,,-- H. Douville, J. Polcher, and P. J. Valdes, 2000: Characterizing GCM land surface schemes to understand their responses to climate change. J. Climate, 13, 3066-3079.

Gurtz, J., M. Zappa, K. Jasper, H. Lang, M. Verbunt, A. Badoux, and T. Vitvar, 2003: A comparative study in modeling runoff and its components in two mountainous catchments. Hydrol. Processes, 17, 297-311.

Hansen, M. C., R. Defries, J. R. G. Townshend, and R. Sohlberg, 2000: Global land cover classification at $1 \mathrm{~km}$ spatial resolution using a classification tree approach. Int. J. Remote Sens., 21, 1331-1364.

Hirschi, M., S. I. Seneviratne, and C. Schär, 2006: Seasonal variations in terrestrial water storage for major midlatitude river basins. J. Hydrometeor., 7, 39-60.

Houghton, J. T., Y. Ding, D. J. Griggs, M. Noguer, P. J. van der Linden, X. Dai, K. Maskell, and C. A. Johnson, Eds., 2001: Climate Change 2001: The Scientific Basis. Cambridge University Press, $881 \mathrm{pp}$.

Kleinn, J., C. Frei, J. Gurtz, D. Lüthi, P. L. Vidale, and C. Schär, 2005: Hydrologic simulations in the Rhine basin driven by a regional climate model. J. Geophys. Res., 110, D04102, doi:10.1029/2004JD005143.

Koster, R. D., and P. C. D. Milly, 1997: The interplay between transpiration and runoff formulations in land surface schemes used with atmospheric models. J. Climate, 10, 1578-1591.

, M. J. Suarez, A. Ducharne, M. Stieglitz, and P. Kumar, 2000: A catchment-based approach to modeling land surface processes in a general circulation model. 1 . Model structure. $J$. Geophys. Res., 105, 24 809-24 822.
— and Coauthors, 2004: Regions of strong coupling between soil moisture and precipitation. Science, 305, 1138-1140.

Liang, X., and Coauthors, 1998: The Project for Intercomparison of Land-Surface Parameterization Schemes PILPS phase 2c Red-Arkansas River basin experiment: 2. Spatial and temporal analysis of energy fluxes. Global Planet. Change, 19, 137159.

Lohmann, D., and Coauthors, 1998: The Project for Intercomparison of Land-Surface Parameterization Schemes PILPS phase 2c Red-Arkansas River basin experiment: 3. Spatial and temporal analysis of water fluxes. Global Planet. Change, 19, 161-179.

, and Coauthors, 2004: Streamflow and water balance intercomparisons of four land surface models in the North American Land Data Assimilation System Project. J. Geophys. Res., 109, D07S91, doi:10.1029/2003JD003517.

Nicholls, M. E., A. S. Denning, L. Prihodko, P.-L. Vidale, I. Baker, K. Davis, and P. Bakwin, 2004: A multiple-scale simulation of variations in atmospheric carbon dioxide using a coupled biosphere-atmospheric model. J. Geophys. Res., 109, D18117, doi:10.1029/2003JD004482.

Nijssen, B., and Coauthors, 2003: Simulation of high latitude hydrological processes in the Torne-Kalix basin: PILPS phase 2(e) - 2: Comparison of model results with observations. Global Planet. Change, 38, 31-53.

Niu, G.-Y., Z.-L. Yang, R. E. Dickinson, and L. E. Gulden, 2005: A simple TOPMODEL-based runoff parameterization (SIMTOP) for use in global climate models. J. Geophys. Res., 110, D21106, doi:10.1029/2005JD006111.

Pielke, R. A., Sr., G. E. Liston, J. L. Eastman, and L. Lu, and M. Coughenour, 1999: Seasonal weather prediction as an initial value problem. J. Geophys. Res., 104, 19 463-19 479.

Pitman, A. J., 2003: Review the evolution of, and revolution in, land surface schemes designed for climate models. Int. J. Climatol., 23, 479-510.

Schär, C., D. Luthi, U. Beyerle, and E. Heise, 1999: The soilprecipitation feedback: A process study with a regional climate model. J. Climate, 12, 722-741.

Sellers, P. J., and Coauthors, 1996: A revised land surface parameterization (SiB2) for atmospheric GCMS. Part I: Model formulation. J. Climate, 9, 676-705.

_ and Coauthors, 1997: Modeling the exchanges of energy, water, and carbon between continents and the atmosphere. Science, 275, 502-509.

Seneviratne, S. I., D. Luthi, M. Litschi, and C. Schar, 2006: Landatmosphere coupling and climate change in Europe. Nature, 443, 205-209.

Stieglitz, M., D. Rind, J. Famiglietti, and C. Rosenzweig, 1997: An efficient approach to modeling the topographic control of surface hydrology for regional and global climate modeling. J. Climate, 10, 118-137.

Stöckli, R., and P. L. Vidale, 2004: European plant phenology and climate as seen in a 20-year AVHRR land-surface parameter dataset. Int. J. Remote Sens., 25, 3303-3330.

— exchanges at European Fluxnet sites. Theor. Appl. Climatol., 80, 229-243.

USGS, cited 1996: GTOPO30. U.S. Geological Survey, National Mapping Division, EROS Data Center, Sioux Falls, SD, digital media. [Available online at http://edcdaac.usgs.gov:80/ gtopo30/gtopo30.html.]

Vidale, P. L., and R. Stöckli, 2005: Prognostic canopy air space 
solutions for land surface exchanges. Theor. Appl. Climatol., 80, 245-257.

Walko, R. L., and Coauthors, 2000: Coupled atmosphere-biophysics-hydrology models for environmental modeling. $J$. Appl. Meteor., 39, 931-944.

Western, A. W., R. B. Grayson, and G. Blosch, 2002: Scaling of soil moisture: A hydrologic perspective. Annu. Rev. Earth Planet. Sci., 30, 149-180.

Wood, E. F., and Coauthors, 1998: The Project for Intercompari- son of Land-Surface Parameterization Schemes PILPS phase 2c Red-Arkansas River basin experiment: 1. Experiment description and summary intercomparisons. Global Planet. Change, 19, 115-135.

Yang, Z.-L., and G.-Y. Niu, 2003: The versatile integrator of surface atmospheric processes. Part 1: Model description. Global Planet. Change, 38, 175-189.

Zeng, X., 2001: Global vegetation root distribution for land modeling. J. Hydrometeor., 2, 525-530. 